Népegészségügy - Eredeti közlemény / Public health - Original article

Moskola Vladimír', Szabó Gábor², Susánszky Éva³, Székely Andrea', Hornyák István', Ozsvárt Barbara', Néninger Tibor', Balogh Zoltán

'Semme/weis Egyetem, Egészségtudományi Kar, Oxiológia és Sürgősségi Ellátás Tanszék, Budapest - Semmelweis University, Faculty of Health Sciences, Department of Oxiology and Emergency Care, Budapest

${ }^{2}$ Metropolitan Egyetem, Tréningközpont, Budapest - Metropolitan University, Training Center, Budapest

3 Semmelweis Egyetem, Általános Orvostudományi Kar, Magatartástudományi Intézet, Budapest Semme/weis University, Faculty of Medicine, Department of Medical Psychology, Budapest

${ }^{4}$ Semmelweis Egyetem, Egészségtudományi Kar, Ápolástan Tanszék, Budapest - Semmelweis University, Faculty of Health Sciences, Department of Nursing, Budapest

\title{
A szülöi nevelés hatása a halálelkerülésre és a halálfélelemre kivonuló mentödolgozók körében
}

\author{
Impact of parenting on death avoidance and fear of \\ death among emergency ambulance crew members
}

\section{Összefoglalás}

A kivonuló mentődolgozókat a kórházi egészségügyi tevékenységet ellátókhoz képest Magyarországon igen kis mértékben vizsgálták, annak ellenére, hogy ismert a helyszín adta különleges, változatos környezet és az abból adódó különbözőségek. A hospitális halálfélelem és halálelkerülés vizsgálatok eredményeit ismerve egy új megközelítésben kezdtük vizsgálni a kivonuló mentődolgozó- 
kat, ismerve azt az összefüggést, hogy a halálfélelem túlzott megjelenése, nem megfelelő kezelése hosszú távon jelentősen befolyásolja a szorongást, ezen keresztül a minőségi mentőmunkát. A megfelelő intervenciók kidolgozásához előzetes ismeretekre van szükség a célcsoportban. Ennek okán a szülői bánásmódot, a megküzdést, konfliktusmegoldó képességet kezdtük el vizsgálni a halálattitűddel kapcsolatban. Keresztmetszeti, prospektív elemekkel rendelkező kvantitatív jellegű vizsgálatunkat országos TUKEB engedély birtokában végeztük. Az online kérdőív zárt rendszeren belül, csak a célcsoportnak juttattuk el, az anonimitás biztosítása mellett.. A beérkező adatokat az SPSS V25 program segítségével elemeztük, a leíró statisztika mellett regressziós analízist végeztünk. Az elemzések alapján kiderült, hogy a túlvédő szülői bánásmód (beleszólás, korlátok és aggódás) és az apai túlsúlyú megjelenés kis mértékben a nőknél, de dominánsan a férfiak körében közvetlenül és a megküzdés különböző módjain keresztül közvetett módon befolyásolják a halálfélelmet és a halálelkerülést. A kórházi egészségügyi tevékenységet végző személyekhez képest (ápoló, orvos, medikus) a kivonuló mentődolgozók körében a halálfélelem és a halálelkerülés nagyobb hangsúllyal van jelen, amely fokozza a szorongást és ezáltal befolyásolja a minőségi mentőellátást.

Kulcsszavak: szülői bánásmód, magatartásforma, mentődolgozó, halálattitűd, megküzdés

\section{Abstract}

Compared to hospital health care workers, emergency ambulance personnel have been studied to a very small extent in Hungary, despite the fact that their work environment is special and diverse, so the resulting differences are given, too. Knowing the results of fear of death and death avoidance studies, 
we started to examine emergency ambulance crew members in a new approach, knowing the effect that the excessive presence and inadequate treatment of fear of death significantly affects anxiety in the long run, and it affects quality rescue work. Prior knowledge of the target group is required to develop appropriate interventions. For this reason, we began to examine parental upbringing attitudes, coping mechanisms and conflict resolution, in relation to death attitude. We started our quantitative study with cross-sectional, prospective elements in possession of a national ethical (TUKEB) permission. Data were provided only to the target group through a closed system using an online questionnaire, anonymity was ensured. The incoming data were analyzed using the SPSS V25 software; regression analysis was performed in addition to descriptive statistics. Analyses have shown that parental upbringing that belongs to the group of overprotection (Intervention, Constraints, and Worrying) and paternal predominance slightly in women but predominantly in men directly, through various ways of coping indirectly affects fear of death and death avoidance. Compared to performing hospital health care workers (nurse, doctor, physician), in the case of emergency ambulance personnel fear of and avoidance of death is present with a greater emphasis, which increases anxiety and thereby affects quality ambulance care.

Keywords: parental upbringing, behavior, ambulance worker, death attitude, coping 


\section{EGÉSZSÉGTUDOMÁNY}

2020;64(4): 100-123

HEALTH SCIENCE

Közlésre érkezett: 2020. augusztus 28.

Submitted: 28 August 2020

Elfogadva: 2020. szeptember 22.

Accepted: 22 September 2020

Levelezési cím/Correspondence:

Moskola Vladimír

Semmelweis Egyetem Egészségtudományi Kar, Oxiológia és Sürgősségi Ellátás Tanszék

1088 Budapest, Vas u. 17.

E-mail: moskolav@gmail.com

Tel.: +36203969981

\section{Bevezetés}

A szülői nevelés és bánásmód, a családi szocializáció jelentős szerepet játszik a személyiség fejlődésében, alakulásában. Becker és Schaefer szerint a szülői attitüdök a kontroll és az ér- zelmi dimenzió mentén határozhatók meg. A kontroll két végpontja az engedékenység és a korlátozás. Az engedékenység segítheti a gátlások leküzdését, de lehetnek negatív hatásai, míg a korlátozás visszafogja, szabályozza a viselkedést. Az érzelmi dimenzió egyik végpontja az elutasító, hideg szülői attitüd, ami megnyilvánulhat abban, hogy a szülők kiabálnak, lekicsinylő módon bánnak a gyermekkel és megszégyenítik, büntetik őt. Ugyanezen dimenzió másik végpontja a szerető, elfogadó beállítódás, ami nem a személyiséget, hanem a tettet minősíti, megmagyarázza a cselekedet helytelen voltát és feltételezetett okát, káros következményeit 1,2. Baumrind, Becker és Schaefer modelljétől eltérően, kutatásai alapján három féle bánásmódot határozott meg. Az első a tekintélyelvüség, amely az engedelmesség megkérdőjelezhetetlenségén alapszik. Ezen stílust használó szülők gyermekei felnőttkorban a szociális érintkezést háttérbe szorítják, inkább introvertáltak. Az engedékeny szülői nevelés eredménye, hogy a gyermekek felnőtt korukban önállótlanabbak, pszichésen labilisak lesznek, 
indulataikat nem tudják megfelelően kezelni. A mérvadó szülők szabálytartóak, a gyermekek kötelességeit ugyanoIyan fontosnak tartják, mint a jogaikat, konzekvens nevelést alkalmaznak. Ezek a gyermekek felnőtt korukra önállóak lesznek, és rendelkeznek azokkal a szükséges alapokkal, amelyek segítik őket a mindennapi kihívások és stresszhelyzetek leküzdésében ${ }^{3,4}$.

Kutatásunk során a Ranschburg-féle szülői attitűdtipizálást vettük figyelembe, amely szerint négy nevelési attitűd, a meleg-engedékeny, a meleg-korlátozó, a hideg-korlátozó és a hideg-engedékeny szülői bánásmód létezik. A melegség alatt a szeretetteljes viselkedést értik. A hideg magatartásra a távolságtartó, időnként elutasító viselkedés jellemző. Az engedékeny szülő szabályrendszere rugalmas, bizonyos érvek mentén kivételeket enged meg, míg a korlátozó szülő szigorú szabályokat határoz meg, melyek be nem tartása komoly büntetést von maga után. Ezen dimenziók meghatározott kombinációi alapján jönnek létre a fent említett szülői attitűdök, melyek várha- tó hatásai a következőkben foglalhatók össze: a hideg-engedékeny nevelés hatására az egyént felnőtt korára antiszociális, deviáns viselkedés jellemezheti, a hideg-korlátozó környezetben felnőttek általában súlyos belső konfliktusokkal élnek, szorongásos és torzult személyiség alakulhat ki, a meleg-engedékeny szülők gyermekei felnőtt korukban kreatívabbak, nyitott személyiségűek, barátságosak, empatikusabbak, a meleg-korlátozó szülők esetében a túlvédés dominál, ezen gyermekek felnőtt korukban agresszívebbek lesznek, de ez befelé irányul, mely hatására erős szorongás jellemzi majd őket ${ }^{5,6}$.

Kutatásunk során azt vizsgáltuk, hogy a szülői attitüdök befolyással vannak-e, és milyen mértékben egy olyan foglalkozási csoport, mint a mentődolgozók halállal kapcsolatos attitűdjére, akik számára a hírtelen, váratlan, erőszakos halál a mindennapok része, és akiknek munkája empatikus, szorongás- és indulatmentes személyiséget kíván. A szülői neveltetésen, bánásmódon kívül a halállal kapcsolatos attitüdök is befolyással lehetnek a pszichés kondícióra, 
a szorongásra, a depressziós állapotok kialakulására, és ezeken keresztül a hatékony, megfelelő és biztonságos mentőellátás kivitelezésére.

A kilencvenes évek elején Buckman egy háromlépcsős elméletet hozott létre, miszerint egy stresszhelyzetre adott megküzdési mechanizmus, melyet korábban valaki nehéz helyzetek kezelésére használt, megegyezhet azzal a módszerrel, amellyel arra reagál, amikor szembesül a bekövetkezett vagy várható halál tényével 7. A tudatosság fáziselmélete az egészségügyi dolgozók és a betegek közötti kommunikáció és viselkedés meghatározó szempontjait tárgyalja. Glaser és Strauss az ellátók és a haldoklók közötti tudatos kommunikáció négy formáját különböztetik meg: zárt tudatosság, amikor az ellátók tisztában vannak a beteg közelgő halálával, ám a páciensnek ezt még nem mondják el, a gyanú tudatossága, amikor a beteg kezdi sejteni a rossz prognózist, a halálos kimenetet, és ennek megerősítésére információt gyűjt a környezetéből, a kölcsönös színlelt állapot, amikor mind az ellátó, mind a beteg tisztában van azzal, hogy a páciens a haldoklás fázisában van, ennek ellenére úgy viselkednek, mintha reális esélye lenne a súlyos állapotból való kilábolásnak, és végül a nyitott tudatosság állapota, amikor mind a két fél tetteivel is elismeri a haldoklás tényét 7,8. Ugyancsak megemlítendő Pattison, aki az ellátók megfelelő viselkedését írja le a haldoklás folyamatában. Ez a klinikai modell a pszichodinamikus és humanista megközelítés kombinációjából származik, figyelembe veszi a beteg érzéseit és reakcióit, valamint a család szempontjait a halállal való megküzdés és veszteség elfogadásának folyamatában. Itt az egészségügyi ellátó fő szerepét a klinikai haldoklás három fő szakasza mentén határozza meg (akut krízis fázis, krónikus halálos fázis és végső fázis). Célja, hogy optimalizálja az akut krízis fázis és a krónikus fázis megfelelő alkalmazkodását, elfogadását, és átsegítsen a végső fázisba 9. Látható, hogy az egészségügyi ellátókkal szemben komoly elvárások fogalmazódnak meg a haldoklók ellátásával kapcsolatban, amelyet amúgy is fokozott stresszként élnek meg. Mindehhez hozzáadódik 
az ellátó személyes, az esetek jelentős részében nem megfelelően kezelt halálfélelme vagy halálelkerülése, mely kiválthat szorongásos vagy depressziós állapotot, illetve a meglévők progressziójához vezethet.

A következőkben a szülői neveltetés egyes kiemelt típusai és a halálelkerülés, halálfélelem, valamint a megküzdés különböző elemei közötti összefüggéseket vizsgáljuk. Ezen összefüggések vizsgálata Magyarországon, a mentődolgozók körében kutatás tárgyát még nem képezte. Célunk olyan összefüggések azonosítása és feltárása volt, amelyek alapján a kivonuló mentődolgozók számára hatékony intervenciós programokat lehet kidolgozni a halálfélelem megfelelő kezelésére, valamint a hatékony megküzdési mechanizmusok alkalmazására. A kivonuló mentődolgozók az egészségügyben egyedülálló módon csak itt tapasztalt sajátosságok, a környezet és a helyszín miatt különleges csoportot képeznek. Ezen foglalkozási csoport vizsgálata a hazai egészségtudományon belül is még viszonylag érintetlen, a paramedi- kális kutatások nemzetközi kitekintésben is egy fiatal és dinamikusan fejlődő tudományág részét képezik. Úgy véljük, hogy a hatékony betegellátás egyik alapja a szakellátók megfelelő testi és lelki, pszichés egészsége, valamint egészségének fenntartása, időszakos intervenciókon keresztül.

\section{Anyag és módszerek}

Kutatásunk típusát tekintve keresztmetszeti, prospektív elemekkel rendelkező kvantitatív jellegü vizsgálat. Ezen kutatást az országos Egészségügyi Tudományos Tanács Tudományos és Kutatásetikai Bizottsága (ETT TUKEB) engedélyezte (11994-2/2018). Felmérésünket online módon az Országos Mentőszolgálat (OMSZ) állományában dolgozó kivonuló munkatársak körében végeztük el 2018. március 1. és 2019. február 28. között. A kitöltési kritériumba tartozott, hogy a válaszadó legalább hat hónapja dolgozik a mentőszolgálatnál. A kérdőívet az OMSZ belső, zárt rendszerü, valamint a Magyar Egészségügyi Szakdolgozói Kamara (MESZK) Orszá- 
gos Mentésügyi Szakmai Tagozatában nyilvántartott dolgozók e-mail címére küldtük ki. A beérkezett 669 kérdőívből 658 volt értékelhető. Az OMSZ-nál a kérdőívfelvétel időszakában 6412 fő volt aktív állományban, a férfiak aránya 88, a nők aránya pedig 12 százalék volt. A felmérésben részvevők nemi megoszlása megegyezett az aktív állományt jellemző nemi arányokkal.

Kutatásunk során három validált kérdőívet alkalmaztunk, valamint demográfiai, egészségmagatartási és munkahelyre vonatkozó kérdéseket tettünk fel. Első kérdőívünk a Perris-féle szülői nevelői attitűdöket a gyermek, nevelt, alárendelt oldaláról vizsgáló Egna Minnen Beträffande Uppfostran (EMBU) kérdőív Arrindel által létrehozott, rövidített 23 kérdéses változata volt (s-EMBU), melyet Magyarországon Kállai (1994) alkalmazott először. A kérdőív három alskálájának, nevezetesen a Melegség, az Elutasítás és a Túlvédés faktoroknak populációnkra történő újrafaktorizálása során a túlvédésen belül újabb alskálákat sikerült létrehozni Beleszólás, Aggódás és Korlátozás címkékkel. A halállal kapcsolatos attitüdök mérésére kidolgozott Halálattitűd-profil kérdőívének revideált Wong által kidolgozott változatát használtuk (DAP-R), amely összesen 32 tételből áll, és öt skálán méri a halálhoz füződő attitüdöket, melyek a következők: Halálelkerülés, Várakozásteli elfogadás, Elfogadás menekülésként, Halálfélelem, Semleges elfogadás. A kérdőív Kulcsár (2002) által közölt változata az eredetiből csak 28 tételt tartalmaz, így a magyar változat véglegesítését - a hiányzó tételek fordítását, a tételek nyelvi egységesítését - Varga és társai, valamint a mi munkacsoportunk végezte, és az eredeti faktorstruktúra alapján használtuk fel ${ }^{10}$. A kutatás alatt viszont kiderült, hogy az eredeti kérdőívet Magyarországon hivatalos formában még nem fordították le, így ezt a DAP-R vonatkozásában megtettük és erről szóló publikációnk kiadás alatt van. A megküzdési módok vizsgálatára a Folkman-Lazarus-féle kérdőív rövidített, 22 tételes verzióját (WOC-22) használtuk, melyet Magyarországon Rózsa és munkatársai validáltak. A vizsgálati populációból származó adatok elemzése során az 
újrafaktorizálást követően az eredetihez képest a következő új alskálák lettek meghatározva: feszültség redukció, kognitív átstrukturálódás, probléma elemzés és a kockázat keresés. Az adatelemzés az SPSS PC. 25.0 verziójú (IBM Corp. Released 2017., Armonk, NY) statisztikai programmal készült. Leíró statisztikát és Lineáris regressziós elemzést végeztünk, amely során első lépésben a szülői-nevelői attitűd különböző faktorai és a halálfélelem, illetve halálelkerülés közötti kapcsolatot vizsgáltuk. A következő lépésben mediátorváltozóként bevontuk a modellbe a megküzdés különböző faktorait. Célunk volt kideríteni, hogy a megküzdés mely esetekben szerepel közvetítő változóként. Ezekben az esetekben ugyanis a megküzdés és a halálfélelem, illetve halálelkerülés közötti szignifikáns kapcsolat eredményeként a szülői-nevelői attitűd különböző faktorai és a halálfélelem, illetve halálelkerülés közötti szignifikáns kapcsolat lecsökken vagy el is tűnik. A szignifikancia szintet $\mathrm{p}<0,05$ értékben határoztuk meg.

\section{Eredmények}

\section{A résztvevők demográfiai jellemzői}

A feldolgozott kérdőívek alapján kutatási mintánkban, ahogy a teljes szakdolgozói populációban is, a férfiak vannak jelentős többségben (87,6\%). A felmérésben részvevőket életkoruk alapján öt csoportba soroltuk, a válaszadók 32,5 százaléka a 36-45 éves korosztályba sorolható. Az iskolai végzettség leírására négy kategóriát használtunk. A válaszadók 40 százaléka felsőfokú iskolai végzettséggel, legtöbben pedig OKJ képzéssel rendelkeztek (36,8\%). Családi állapotuk tekintetében a házasok (59,5\%) képezték a domináns, nagyobb csoportot. Legnagyobb arányban a kétgyermekesek válaszoltak a kérdőívben (31,2\%), a gyermektelenek 26,1 százalékban voltak jelen. A részvevők legnagyobb arányban városban nevelkedtek (41,2\%), a minta egyharmada (36,5\%) pedig falun. A legtöbben saját lakásban élnek (42,4\%), valamint saját kertes-családi házban (42,3\%). A kitöltők 54,2 százaléka nem gyakorol semmilyen vallást. 
Népegészségügy - Eredeti közlemény / Public health - Original article

\section{Munkával, munkahellyel kapcsolatos jellemzők}

A válaszadók legnagyobb arányban mentőápolók $(46,4 \%)$ és mentőtisztek $(28,1 \%)$ voltak. A mentőszolgálatnál eltöltött éveket vizsgálva legtöbben (32,9\%) 1-10 éve dolgoznak a szolgálatnál. Legtöbben a Közép-Magyarországi $(22,7 \%)$ és a Dél-Alföldi (18,6\%) régióból töltötték ki a kérdőívet. A résztvevők legnagyobb arányban esetkocsin (45,6\%) és mentőgépkocsin (42,1\%) dolgoznak. A válaszadók döntő többsége főállású (86,2\%). A munkarend szempontjából a 24 órás müszakot választották a leggyakrabban (45,8\%). Az anyagi helyzettel való elégedettséget vizsgálva meglepő módon csupán 18,3 százalékuk elégedetlen, a dolgozók több mint a fele közepesen elégedett (62,3\%).

Egészségmagatartás, rizikómagatartások

A résztvevők többsége nem dohányzó (67\%). A kávéfogyasztók aránya jelentős, 56,6 százalékuk három, 21,8 százalékuk pedig négynél több kávét fogyaszt

naponta. A résztvevők döntő többsége nem fogyaszt energiaitalt (89,1\%). A minta felét jellemzi, hogy nem, vagy csak ritka alkalmanként iszik alkoholt $(50,7 \%)$, a naponta vagy a hetente többször alkoholt fogyasztók aránya 12,4 százalék. A direkt, aktív mozgás tekintetében a legnagyobb arányban a nem, vagy a nagyon ritkán mozgók vannak jelen, majdnem a válaszadók fele (42,4\%), és a dolgozók 6,3 százaléka mozog naponta.

\section{A szülöi nevelöi attitüdök, a megküz- dés és a halálelkerülés, halálfélelem kapcsolatai}

A következőkben a lineáris regressziós elemzés eredményeit nemi bontásban mutatjuk be. Ahol a bemeneti változók az sEMBU általunk módosított alskálái, célváltozó a DAP-R alskálák közül egyrészt a halálelkerülés, másrészt a halálfélelem volt. Mediátor változóként a WOC alskáláit helyeztük el a modellben. A nők esetében meglepően kevés szignifikáns eredmény született (1. táblázat). 
Népegészségügy - Eredeti közlemény / Public health - Original article

1. táblázat: A szülöi nevelési attitüdök regressziója a halálattitűd kérdöív és a megküzdési, konfliktusmegoldó kérdöív alskáláira, a nőkre és a férfiakra vonatkoztatva $(p<0,05)$

Table 1. Regression of parental upbringing attitudes in relation to the subscales of the death attitude questionnaire and the coping, conflict resolution questionnaire, for women and men $(p<0.05)$

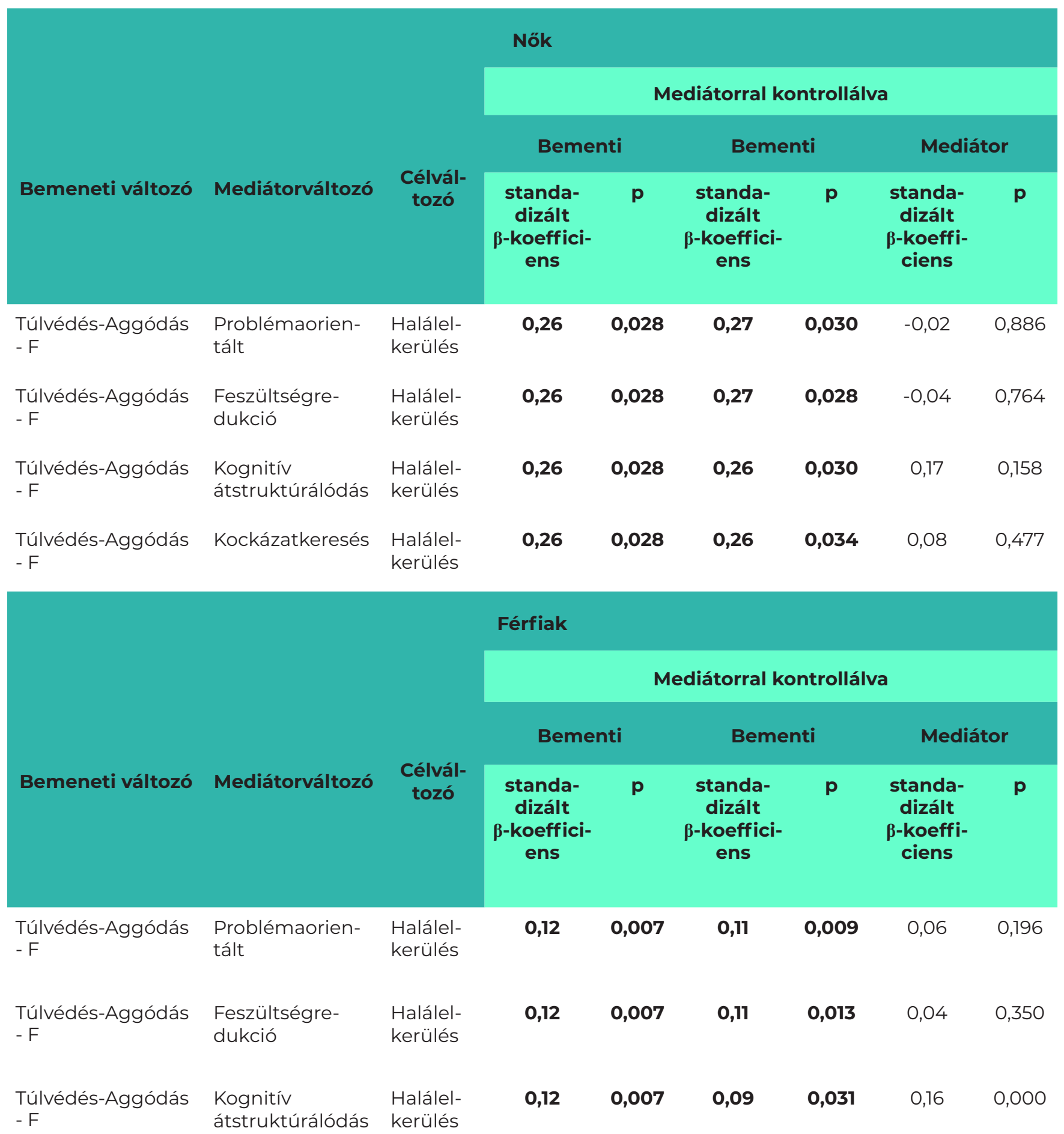




\begin{tabular}{|c|c|c|c|c|c|c|c|c|}
\hline $\begin{array}{l}\text { Túlvédés-Aggódás } \\
\text { - F }\end{array}$ & Kockázatkeresés & $\begin{array}{l}\text { Halálel- } \\
\text { kerülés }\end{array}$ & 0,12 & 0,007 & 0,11 & 0,014 & 0,05 & 0,240 \\
\hline $\begin{array}{l}\text { Túlvédés-Korlátok } \\
\text { - M }\end{array}$ & $\begin{array}{l}\text { Feszültségre- } \\
\text { dukció }\end{array}$ & $\begin{array}{l}\text { Halálfé- } \\
\text { lelem }\end{array}$ & $-0,07$ & 0,079 & $-0,09$ & 0,031 & 0,20 & 0,000 \\
\hline $\begin{array}{l}\text { Túlvédés-Aggódás } \\
\text { - M }\end{array}$ & $\begin{array}{l}\text { Problémaorien- } \\
\text { tált }\end{array}$ & $\begin{array}{l}\text { Halálfé- } \\
\text { lelem }\end{array}$ & 0,11 & 0,007 & 0,11 & 0,008 & 0,02 & 0,707 \\
\hline $\begin{array}{l}\text { Túlvédés-Aggódás } \\
\text { - M }\end{array}$ & $\begin{array}{l}\text { Feszültségre- } \\
\text { dukció }\end{array}$ & $\begin{array}{l}\text { Halálfé- } \\
\text { lelem }\end{array}$ & 0,11 & 0,007 & 0,08 & 0,055 & 0,18 & 0,000 \\
\hline $\begin{array}{l}\text { Túlvédés-Aggódás } \\
\text { - M }\end{array}$ & $\begin{array}{l}\text { Kongnitív } \\
\text { átstruktúrálódás }\end{array}$ & $\begin{array}{l}\text { Halálfé- } \\
\text { lelem }\end{array}$ & 0,11 & 0,007 & 0,10 & 0,017 & 0,14 & 0,001 \\
\hline $\begin{array}{l}\text { Túlvédés-Aggódás } \\
\text { - M }\end{array}$ & Kockázatkeresés & $\begin{array}{l}\text { Halálfé- } \\
\text { lelem }\end{array}$ & 0,11 & 0,007 & 0,10 & 0,014 & 0,11 & 0,008 \\
\hline $\begin{array}{l}\text { Túlvédés-Beleszó- } \\
\text { lás - F }\end{array}$ & $\begin{array}{l}\text { Feszültségre- } \\
\text { dukció }\end{array}$ & $\begin{array}{l}\text { Halálfé- } \\
\text { lelem }\end{array}$ & $-0,07$ & 0,105 & $-0,12$ & 0,005 & 0,22 & 0,000 \\
\hline $\begin{array}{l}\text { Túlvédés-Beleszó- } \\
\text { lás - F }\end{array}$ & Kockázatkeresés & $\begin{array}{l}\text { Halálfé- } \\
\text { lelem }\end{array}$ & $-0,07$ & 0,105 & $-0,09$ & 0,035 & 0,14 & 0,001 \\
\hline $\begin{array}{l}\text { Túlvédés-Korlátok } \\
\text { - F }\end{array}$ & $\begin{array}{l}\text { Problémaorien- } \\
\text { tált }\end{array}$ & $\begin{array}{l}\text { Halálfé- } \\
\text { lelem }\end{array}$ & $-0,11$ & 0,009 & $-0,12$ & 0,007 & 0,04 & 0,272 \\
\hline $\begin{array}{l}\text { Túlvédés-Korlátok } \\
\text { - F }\end{array}$ & $\begin{array}{l}\text { Feszültségre- } \\
\text { dukció }\end{array}$ & $\begin{array}{l}\text { Halálfé- } \\
\text { lelem }\end{array}$ & $-0,11$ & 0,009 & $-0,12$ & 0,004 & 0,20 & 0,000 \\
\hline $\begin{array}{l}\text { Túlvédés-Korlátok } \\
\text { - F }\end{array}$ & $\begin{array}{l}\text { Kongnitív } \\
\text { átstruktúrálódás }\end{array}$ & $\begin{array}{l}\text { Halálfé- } \\
\text { lelem }\end{array}$ & $-0,11$ & 0,009 & $-0,12$ & 0,006 & 0,15 & 0,000 \\
\hline $\begin{array}{l}\text { Túlvédés-Korlátok } \\
\text { - F }\end{array}$ & Kockázatkeresés & $\begin{array}{l}\text { Halálfé- } \\
\text { lelem }\end{array}$ & $-0,11$ & 0,009 & $-0,11$ & 0,013 & 0,11 & 0,009 \\
\hline $\begin{array}{l}\text { Túlvédés-Aggódás } \\
\text { - F }\end{array}$ & $\begin{array}{l}\text { Problémaorien- } \\
\text { tált }\end{array}$ & $\begin{array}{l}\text { Halálfé- } \\
\text { lelem }\end{array}$ & 0,10 & 0,025 & 0,09 & 0,027 & 0,02 & 0,582 \\
\hline $\begin{array}{l}\text { Túlvédés-Aggódás } \\
\text { - F }\end{array}$ & $\begin{array}{l}\text { Feszültségre- } \\
\text { dukció }\end{array}$ & $\begin{array}{l}\text { Halálfé- } \\
\text { lelem }\end{array}$ & 0,10 & 0,025 & 0,07 & 0,124 & 0,18 & 0,000 \\
\hline $\begin{array}{l}\text { Túlvédés-Aggódás } \\
\text { - F }\end{array}$ & $\begin{array}{l}\text { Kongnitív } \\
\text { átstruktúrálódás }\end{array}$ & $\begin{array}{l}\text { Halálfé- } \\
\text { lelem }\end{array}$ & 0,10 & 0,025 & 0,08 & 0,076 & 0,14 & 0,001 \\
\hline $\begin{array}{l}\text { Túlvédés-Aggódás } \\
\text { - F }\end{array}$ & Kockázatkeresés & $\begin{array}{l}\text { Halálfé- } \\
\text { lelem }\end{array}$ & 0,10 & 0,025 & 0,08 & 0,068 & 0,11 & 0,015 \\
\hline
\end{tabular}


A nők csoportját vizsgálva csupán egy szülői nevelési attitűdben észleltünk szignifikáns eredményt, mely az apai aggódás hatásának kapcsolatát mutatja be a halálelkerüléssel. A megküzdési mechanizmusokat is bevonva azt észleltük, hogy ez a kapcsolat közvetlen a mintánkban (1. ábra).

A továbbiakban a férfiak csoportját vizsgáljuk, első szignifikáns összefüggés az apai aggódás alskála esetén látható, mely a halálelkerüléssel mutat közvetlen összefüggést a megküzdési alskálák bevonása után is. Ezen felül a kognitív átstrukturálás közvetlenül külön is hatással van a halálelkerülésre (2. ábra).

Az anyai korlátok és a halálfélelem között első lépésben nem mutatható ki összefüggés, de ha bevonjuk a megküzdés alskáláit, kiderül, hogy valójában van közvetlen negatív kapcsolat közöttük, amely a feszültségredukció és a halálfélelem közötti pozitív irányú kapcsolat miatt nem látszódott (3. ábra).
Az anyai aggódást és a halálfélelmet vizsgálva sikerült közvetlen kapcsolatot kimutatni, viszont ez a kapcsolat a feszültségredukciót bevonása -és csak ebben az egy esetben -megszűnik, tehát ezen szerkezetben vizsgálva kiderül, hogy csupán egy látszólagos kapcsolatról van szó, amely a feszültségredukción keresztül valósul meg, így közvetlen kapcsolat ebben a szerkezeti modellben a halálfélelem és az anyai aggódás között nincs. (4. ábra).

Az anyai aggódás és a halálfélelemet tovább vizsgálva -a feszültségredukciót figyelmen kívül hagyva- közvetlen kapcsolat igazolódik köztük, ez a kapcsolat a kognitív átstruktúrálódás és a kockázatkeresés bevonása után is megmarad. Ugyanakkor az is láthatóvá válik, hogy a kognitív átstruktúrálódás és a kockázatkereső alskálák önmagukban is hatással vannak a halálfélelemre. (5. ábra).

Az apai beleszólásnak bár első ránézésre nincs közvetlen hatása a halálfélelemre, de ha bevonjuk a megküzdési alskálákat, akkor kiderül, hogy 
valójában közvetlen negatív kapcsolat van az apai beleszólás és a halálfélelem között, amelyet a pozitív irányú feszültségredukció általi kapcsolat hatása ellensúlyoz a modellben (6. ábra).

Az apai korlátoknak közvetlen negatív kapcsolata van a halálfélelemmel, amely megmarad a megküzdési alskálák bevonása után is. Ezen felül közvetlen pozitív kapcsolatra is fény derült a halálfélelem és a feszültségredukció, kockázatkeresés és a kognitiv átstrukturálódás között (7. ábra).
Hasonlóan, azt látjuk, hogy az apai aggódás és a halálfélelem között szignifikáns kapcsolat van, de ha bevonjuk a megküzdési alskálákat, akkor ez a kapcsolat megszünik és kiderül, hogy valójában csak egy áttételes kapcsolat van az apai aggódás és a halálfélelem között, amelyet a feszültségredukció, kognitív átstrukturálódás és a kockázatkeresés közvetít (8. ábra).

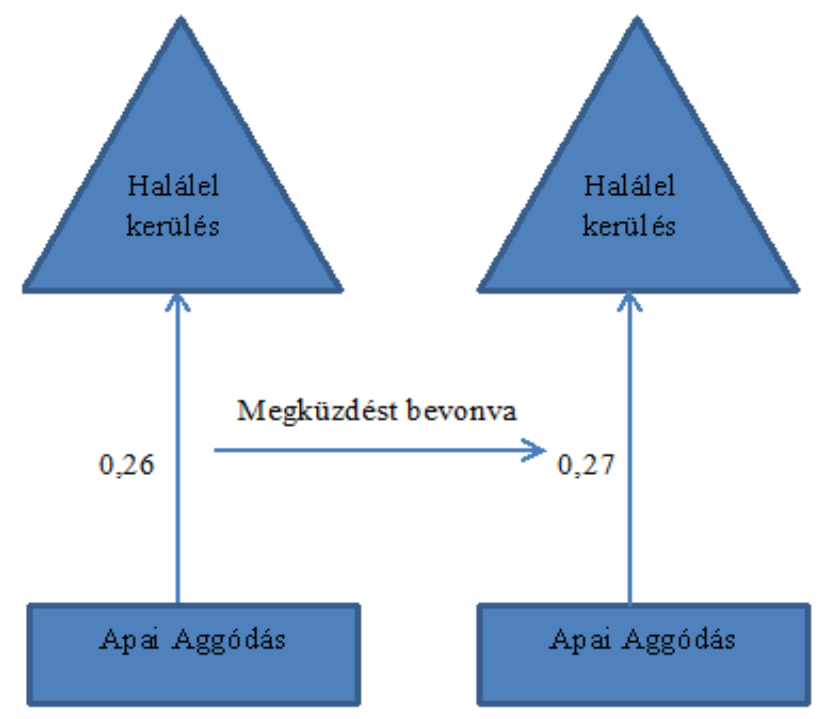

1. ábra: Az apai aggódás közvetlen kapcsolata a halálelkerüléssel a nök körében (a feltüntetett számok a standardizált $\beta$-koefficiens értékeket jelzik)

Figure 1. Direct relationship of paternal worrying to death avoidance among women (numbers shown indicate standardized $\beta$-coefficient values) 


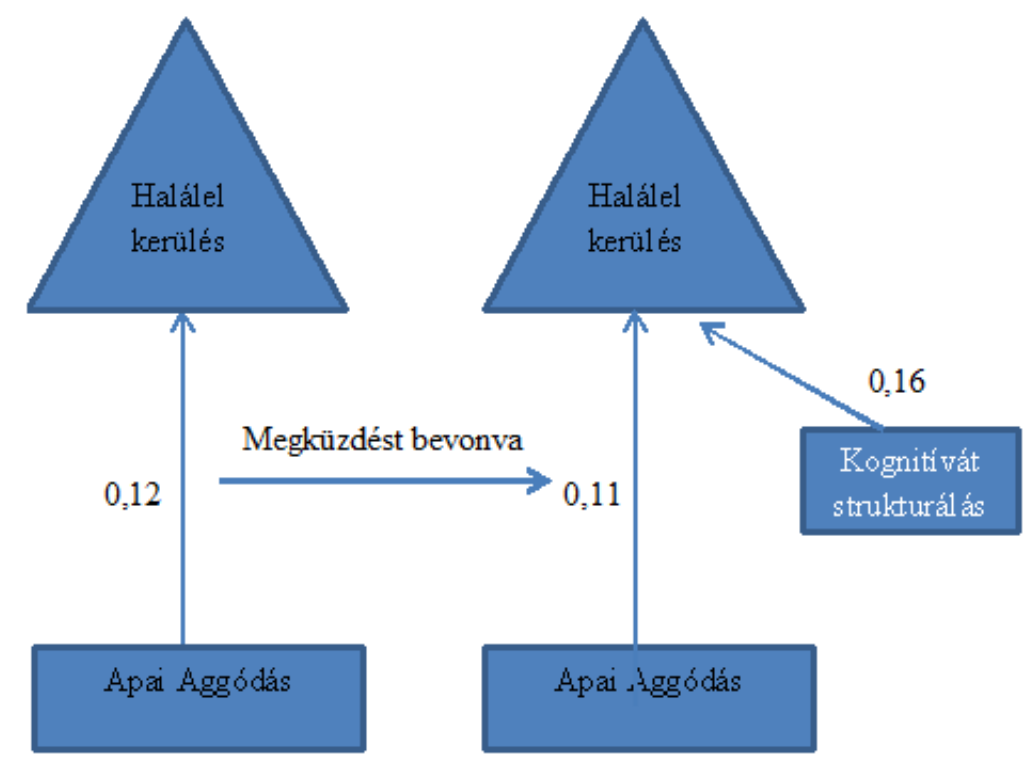

2. ábra: Az apai aggódás és a kognitív átstrukturálódás közvetlen kapcsolata a halálelkerüléssel a férfiak körében (a feltüntetett számok a standardizált $\beta$-koefficiens értékeket jelzik)

Figure 2. Direct relationship of paternal worrying and cognitive restructuring with death avoidance in men (numbers shown indicate standardized $\beta$-coefficient values)

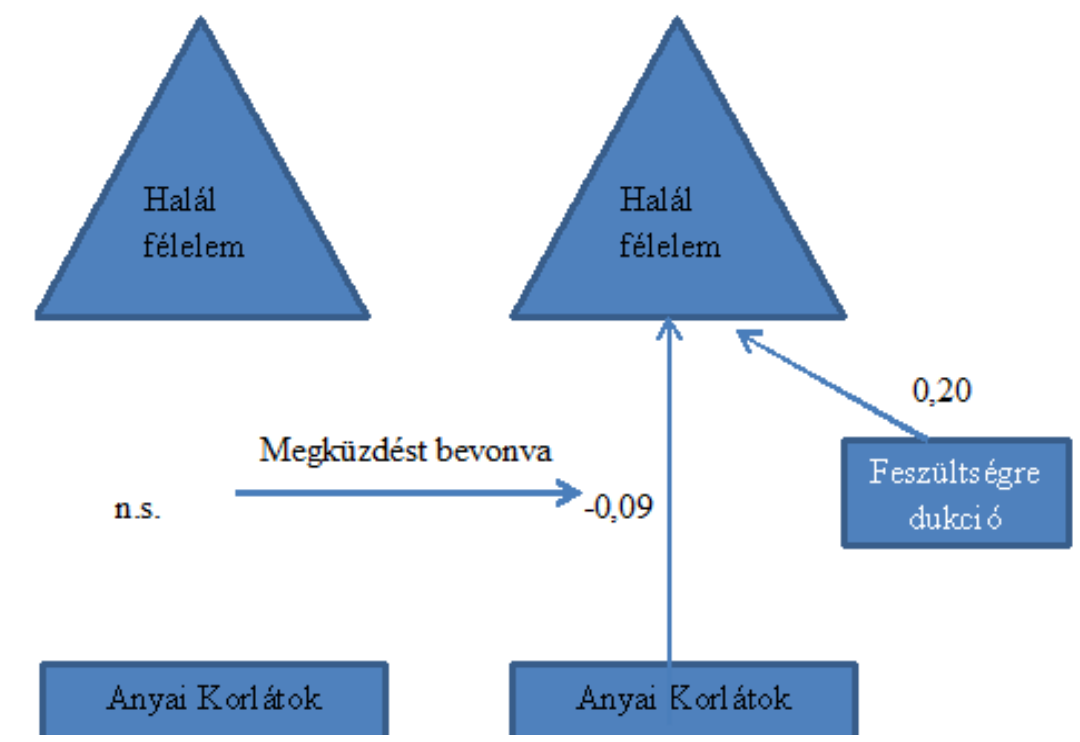

3. ábra: Anyai korlátok hatása a halálfélelemre férfiak körében (a feltüntetett számok a standardizált $\beta$-koefficiens értékeket jelzik)

Figure 3. Effect of maternal constraints on fear of death in men (numbers shown indicate standardized $\beta$-coefficient values 


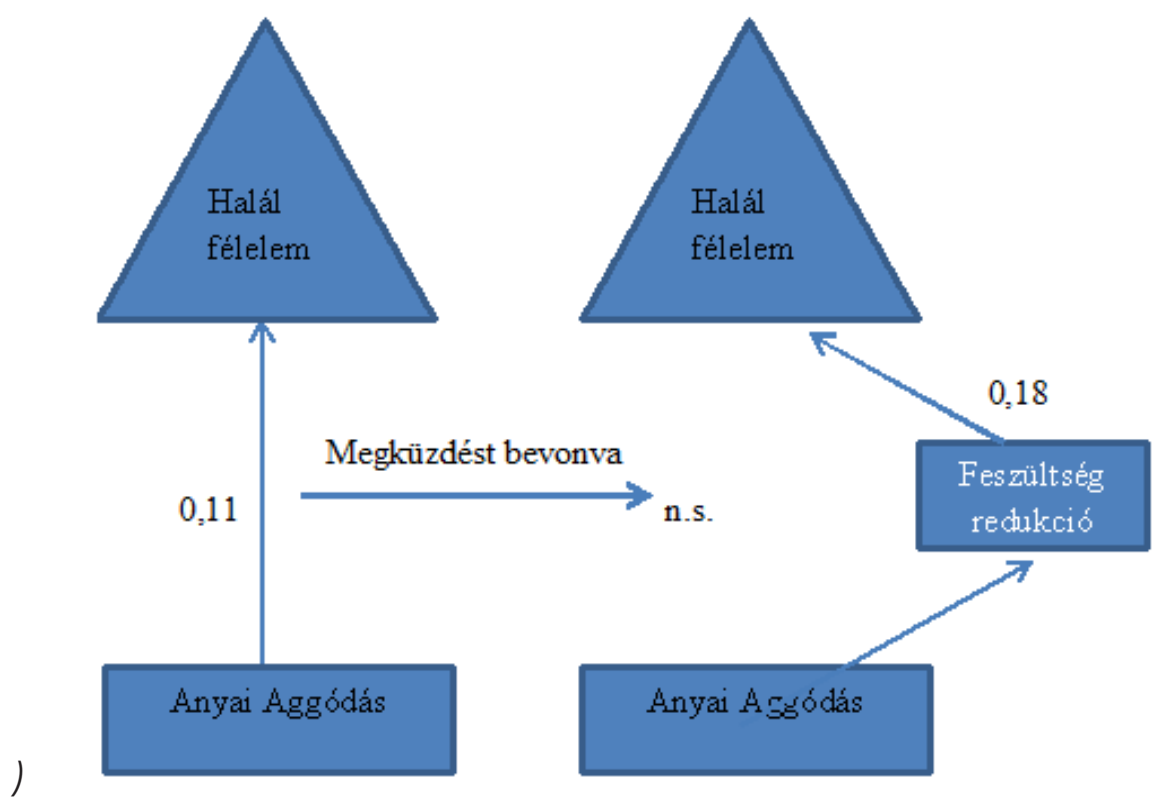

4. ábra: Az anyai aggódás és feszültségredukció kapcsolatai a halálfélelemmel férfiak körében (a feltüntetett számok a standardizált $\beta$-koefficiens értékeket jelzik)

Figure 4. Relationships between maternal worrying and stress reduction with fear of death in men (numbers shown indicate standardized $\beta$-coefficient values)

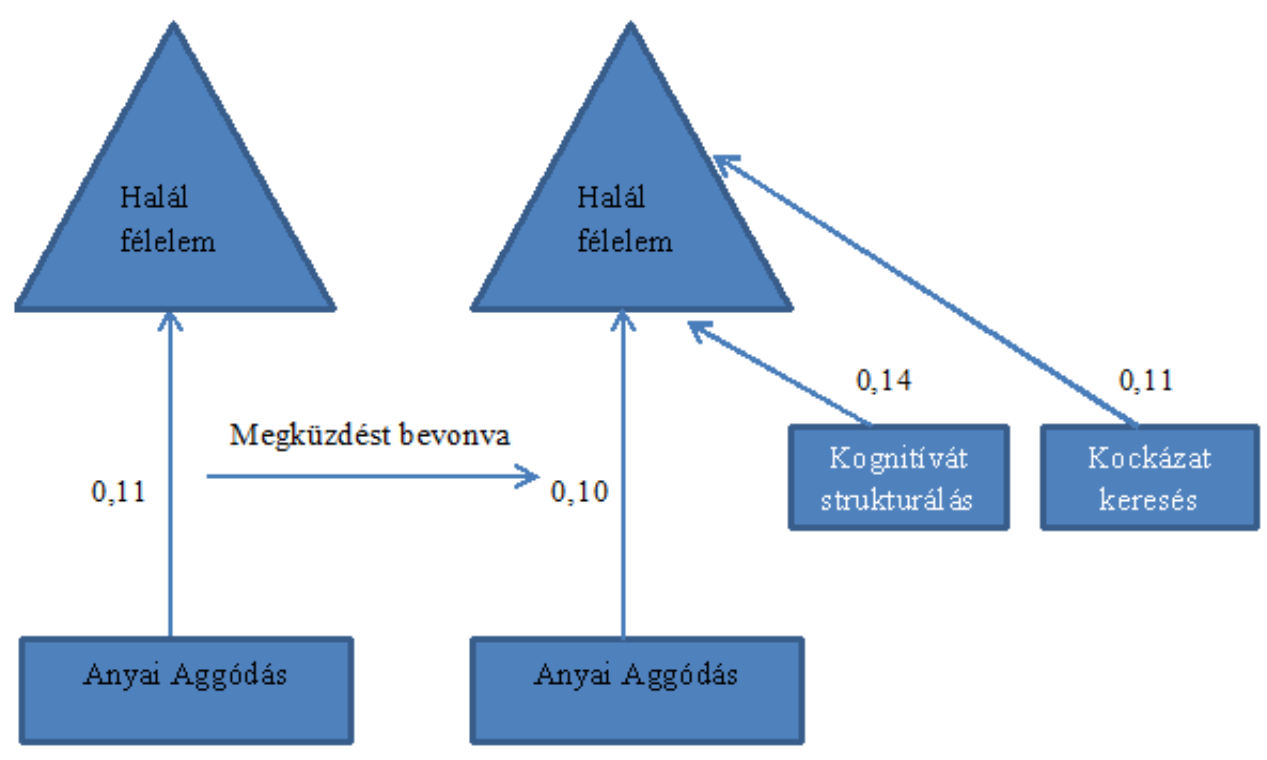

5. ábra: Az anyai aggódás közvetlen, valamint a kognitív átstrukturálódás és a kockázat keresés hatása a halálfélelemre férfiak körében (a feltüntetett számok astandardizált $\beta$-koefficiens értékeket jelzik)

Figure 5. Direct effects of maternal worrying as well as cognitive restructuring and risk-seeking effects on fear of death among men (numbers shown indicate standardized $\beta$-coefficient values) 

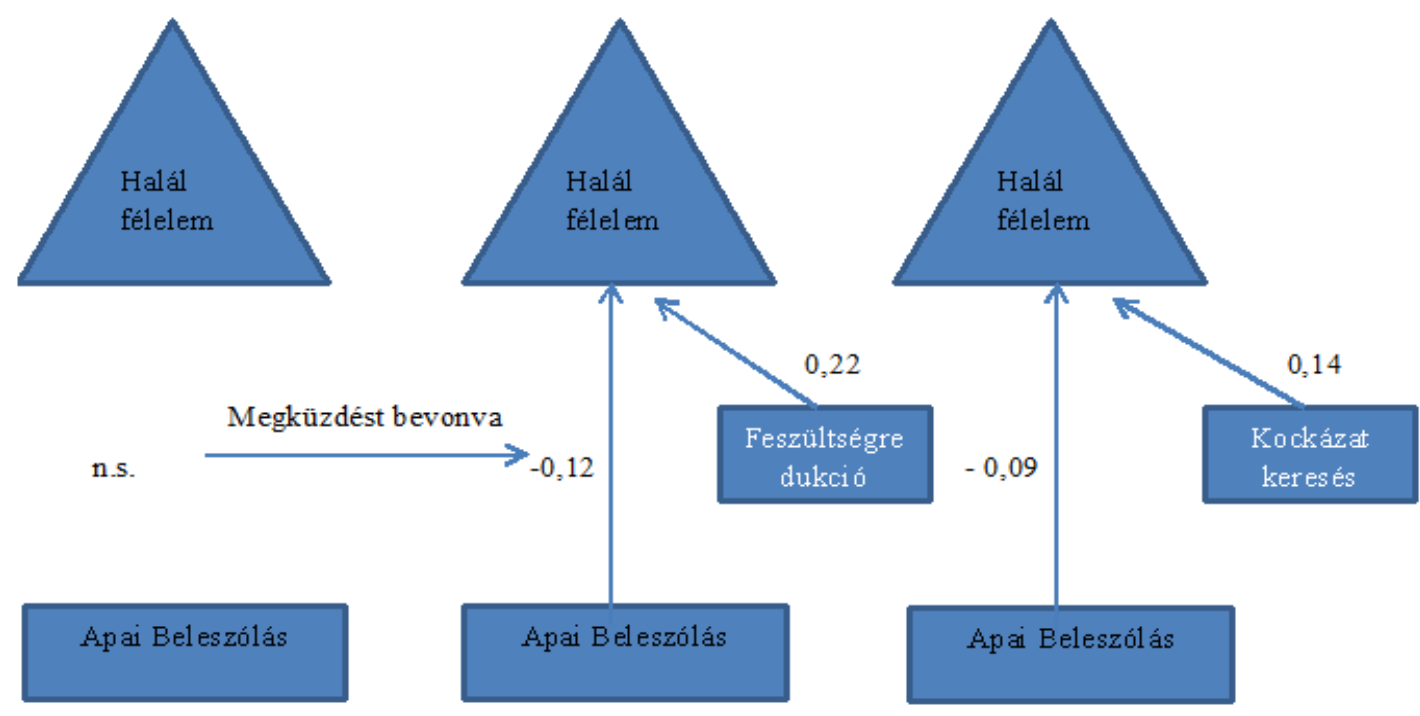

6. ábra: Az apai beleszólás és a halálfélelem kapcsolata a feszültségredukció és a kockázatkeresés bevonásával férfiak körében (a feltüntetett számok a standardizált $\beta$-koefficiens értéket jelzi)

Figure 6. Relationship between paternal intervention and fear of death involving stress reduction and risk-seeking among men (numbers shown indicate standardized $\beta$-coefficient values)
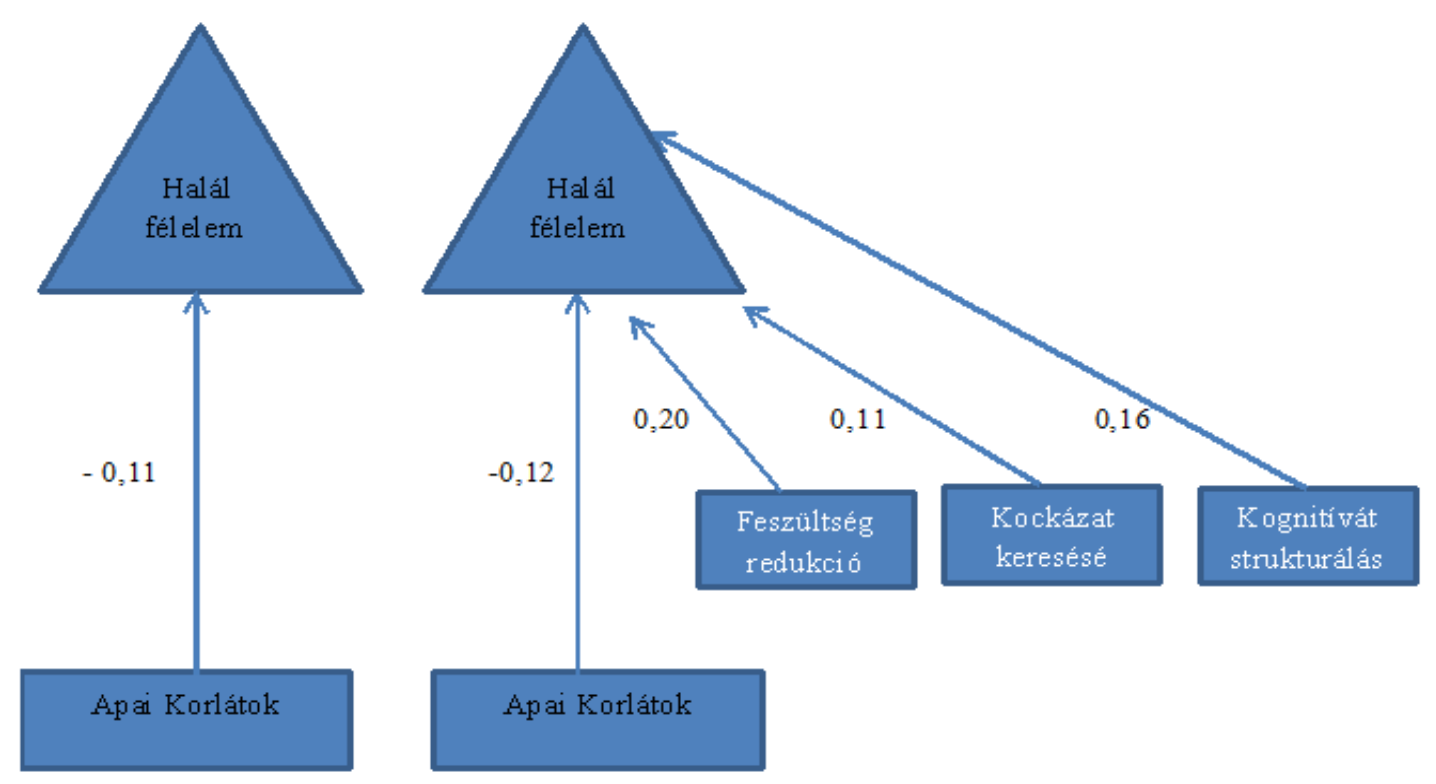

7. ábra: Az apai korlátok negatív kapcsolatai, valamint egyes WOC alskálák pozitív irányú kapcsolatai a halálfélelemmel (a feltüntetett számok a standardizált $\beta$-koefficiens értékeket jelzik)

Figure 7. Negative relationships of paternal constraints and positive relationships of some WOC subscales with fear of death (numbers shown indicate standardized $\beta$-coefficient values) 


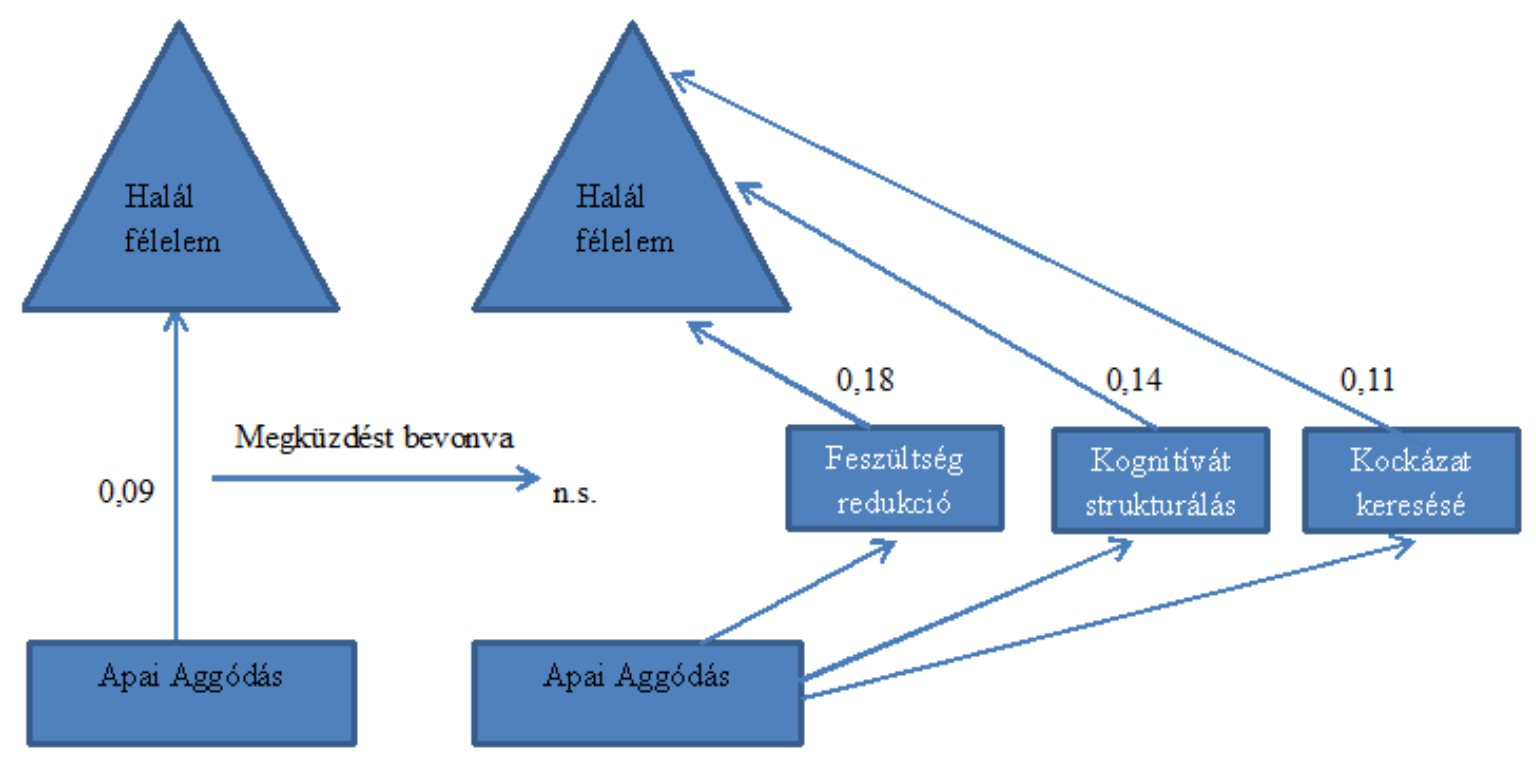

8. ábra Az apai aggódás és egyes megküzdési alskálák közvetlen kapcsolata a halálfélelemmel férfiak körében (a feltüntetett számok a standardizált $\beta$-koefficiens értékeket jelzik)

Figure 8. Direct relationship of paternal worrying and some coping subscales with fear of death

\section{Megbeszélés és következtetések}

Kutatásunk során a szülői neveltetést mértük fel önkitöltős kérdőív segítségével. A kitöltés során a válaszadók emlékeztek vissza szüleik nevelési attitüdjeire és minősítették azokat. Bár a visszaemlékezés időbeli távlatai miatt az emlékek megszépülhetnek, kophatnak, vagy akár torzíthatnak is, mégis jól leírják a szülői bánásmód szubjektív megélését. Vizsgáltuk továbbá, hogy milyen szerepe van a megküzdési mó- doknak, mivel a mindennapi mentőmunka során a kivonuló mentődolgozók jelentős stresszhelyzetnek vannak kitéve. Más egészségügyi dolgozókkal összehasonlítva, munkájuk során gyakrabban találkoznak specifikusan csak a prehospitális ellátásban jellemző váratlan, traumatizáló (lelki, pszichés) gyermek, csonkolásos, azonos korúakkal történt balesetekkel, halálesetekkel, tömeges eseményekkel, kórházi átadásbeli konfliktusokkal (jellemzően a fővárosban) "1. A különböző megküzdési mechanizmusok felmérésével arra 
kerestük a választ, hogy a megküzdési variánsok milyen befolyásoló erővel bírnak a halálelkerülésre és a halálfélelemre. Összetett kutatásunk részeredményeit már korábban publikáltuk hazai és nemzetközi folyóiratokban, fontos leszögezni viszont, hogy a részeredmények elemzése során más statisztikai próbákat használtunk és más szempontokat vizsgáltunk meg, ezen eredményeket jelen cikkünk közvetlenül nem tartalmazza.

A lineáris regressziós modelleket elemezve kiderült, hogy a nők körében csupán egy szülői attitűd mutat összefüggést a halálelkerüléssel, mégpedig az apai aggódás, amely alapján arra következtetünk, hogy a nők esetében az apa aggódó nevelési attitűdje felnőttkorban nagy mértékben valószínüsíti a halálelkerülő attitűd megjelenését. A továbbiakban a férfiak körében vizsgálódva is elmondhatjuk, hogy az aggódó apai háttér esetében nagyobb arányban alakul ki a halálelkerülés. A kognitív átstrukturálódást használó dolgozók esetében kimondhatjuk: halálelkerülés gyakrabban fordul elő, amennyiben aggódó apai attitűdöt tapasztaltak neveltetésük során. A nőkkel ellentétben a férfiak tekintetében számos eredményre derült fény a halálfélelemmel kapcsolatosan, amelyben szerepet játszhat a mintában jelenlévő jelentős arányú férfi túlsúly. A további modellezés során közvetett hatásokat igazoltunk a halálfélelem és a túlvédés tekintetében, melyet szétbontva részletesen vizsgálunk. Elmondható, hogy akiket édesanyjuk (vagy annak tekintett női nevelőjük) korlátok mentén nevelt, azok megküzdési mechanizmusaik során előszeretettel alkalmazzák a feszültségredukciót, amely növeli a halálfélelmet, halálattitüdjükben viszont ebben az esetben annál kevésbé jellemző a halálfélelem, minél korlátozóbb volt az anyai nevelés. Ugyancsak halálfélelem jellemzi azokat a dolgozókat, akik aggódó anyai háttér mellett nevelkedtek, de ez csak közvetett módon a feszültségredukción keresztül érvényesül, közvetlen kapcsolatot nem sikerült kimutatni. Mondhatjuk úgy is, hogy az anyai aggódás feszültségredukció alkalmazására hajlamosít, és ez okoz áttételesen halálfélelmet. Azoknál a dolgozóknál, akik 
problémaorientáltak és aggódó anyai légkörben nevelkedtek fel, kevésbé jellemző a halálfélelem. Az anyai aggódást tovább vizsgálva kiderül, hogy azon mentődolgozókra, akik a kockázatkeresést vagy kognitív átstrukturálódást használják inkább, és neveltetésük során aggódó anyai légkörben nőttek fel, jobban jellemző a halálfélelem, mert a modellben közvetlen kapcsolat igazolódott az anyai aggódás és a halálfélelem között. Eredményeinkből kitűnik azonban az is, hogy azok körében, akik dominánsan a kockázatkeresést, kognitív átstrukturálódást vagy feszültségredukciót használják, önmagában is jelentős mértékben észlelhető a halálfélelem. Azon kivonuló mentődolgozók, akiknél neveltetésük során jobban dominált az apai beleszólás, kevésbé volt jellemző a halálfélelem. Minél nagyobb mértékben volt jelen a neveltetés során az apai beleszólás, annál jobban volt jellemző a kockázatkereső és feszültségredukciós magatartás, és ezek által jellemzőbb volt a halálfélelem. Akiknél neveltetésük során nagyobb mértékben voltak jelen az apai korlátok, kevésbé volt jellemző a halálfélelem. Ez a megállapítás a meg- küzdési módok bevonásával is megállja a helyét. Az is elmondható azonban, hogy a feszültségredukciót, kockázatkeresést és a kognitív átstrukturálódást használó dolgozók körében, ezen megküzdési módok jelenléte önmagukban fokozza a halálfélelmet. Végül, de nem utolsó sorban az apai aggódás nem mutat közvetlen kapcsolatot a halálfélelemmel, áttételes kapcsolata a feszültségredukció, a kognitív átstrukturálódás és a kockázatkeresésen keresztül valósul csak meg. Összességében elmondhatjuk, hogy az anyai hatás mellett kimagaslóan erős az apai hatás és ezen belül a túlvédés különböző formái mind a halálelkerülés, mind a halálfélelem kialakulásában, a nőknél és a férfiaknál egyaránt. A vizsgálati eredményeinkből látható, hogy a kivonuló mentődolgozóknál erős, szignifikáns kapcsolat állapítható meg a túlvédés, valamint alskálái (Beleszólás, Korlátok és az Aggódás), és a halálfélelem, illetve a halálelkerülés között. Oláh és Hegedüs is vizsgálta az ápolók és a laikusok közötti halálfélelmet. Eredményeik szerint magas halálfélelem jellemzi az orvosokat, ápolókat és a medikusokat 12,13. Ugyan- 
ezt támasztja alá Temesváry az orvosok körében, valamint Pék is a mentődolgozókat vizsgálva ${ }^{14,15}$. Ezen eredmények megegyeznek a mi vizsgálati eredményeinkkel is, a szakirodalomban azonban ezekkel ellentétes eredményeket is publikált több kutató ${ }^{16}$. Ennek hátterében Zana szerint az egészségügyi dolgozókra jellemző elfojtás, illetve hárítás állhat, valamint előfordulhat az is, hogy az egészségügyi dolgozók munkájuk során a halállal és a haldoklással kapcsolatban személyes tapasztalatot szereznek. A fenti állítások alapján is magyarázható a halálelkerülés és a halálfélelem előfordulása a mentődolgozók körében. A mentődolgozók körében tapasztalt apai túlvédés a normál populációhoz képest eltérést mutat, hiszen ott az anyai túlvédés van jelentős túlsúlyban ${ }^{17}$. Csomortányi szerint a túlvédés domináns és tartós jelenléte a személyiség fejlődése során erősen hajlamosít a szorongás és a neurotikus személyiségjellemzők kialakulására (az együttes anyai és apai túlvédés ezek fokozottabb megjelenéséhez vezet). Az apai és anyai túlvédést egyszerre átélő egyének több szomatizációt és akár suicid gondolatot is mutatnak, az apai és anyai együttes kontroll (mint esetünkben a túlvédés egyik alskálája) hatására pedig az externalizációs tünetek szaporodnak meg. Ezek alapján láthatjuk, hogy a mentődolgozók milyen kockázati tényezőkkel néznek szembe a mindennapi kivonuló munka során. Míg a túlvédés hatásait közvetlenül utólag nem tudjuk érdemben befolyásolni, így itt csak a feltáró felmérések alapján észlelt rizikófaktorokat, a veszélyeztetett személyek fokozott nyomon követését, szükség esetén gyors intervencióját tudnánk megfelelően kivitelezni. A halálfélelem és halálelkerülés tekintetében kiemelt jelentőséggel bírnának azok a csoportos vagy akár egyéni képzések, amelyek a halállal kapcsolatos negatív attitűdökből származó lelki, pszichés következményeket hivatottak megfelelően rendezni, orvosolni, megelőzni. 


\section{Nyilatkozat}

A cikk végleges változatát a társszerzők is elolvasták a közleményt beadás előtt, valamint hozzájárultak a megjelenéshez.

\section{Anyagi támogatás}

A közlemény megírása, illetve a kapcsolódó kutatómunka anyagi támogatásban nem részesült.

\section{Szerzöi munkamegosztás}

M. V.: Szakirodalom gyüjtése, vizsgálati módszer felállítása, kézirat megszövegezése. Kutatási eszköz kidolgozása, a vizsgálat lefolytatása (adatgyűjtés). Kézirat megszövegezése. Sz.G., M. V., S.É., SZ.A., H.I., O.B., N.T., B.Z.: statisztikai számítások elvégzése. A cikk végleges változatát valamennyi szerző elolvasta és jóváhagyta.

\section{Érdekeltségek}

A szerzőknek nincsenek érdekeltségeik.

\section{Irodalomjegyzék}

1. Becker, W. C. Consequences of Different Kinds of Parental Discipline. In: Review of Child Development Research Eds.I, . [szerk.] M. L., Hoffman, L. W. Russe Hoffman. New York : Sage Foundation, 1964. old.: 169-208. Volume 1.. kötet. http://www.jstor.org/stable/10.7758/9781610446471.8.

2. Kósa, É. Basic Issues of Social Development [A szociális fejlődés alapkérdései.] In : Chapters from the Basic Fields of Psychology. [ Fejezetek a pszichológia alapterületeiből.]. [szerk.] A., Bugán, A Oláh. Budapest : ELTE Eötvös Kiadó, 2001. old.: 259-326.

3. Cole, M., Cole, S. R. A kisgyerekkori fejlődést befolyásoló környezeti hatások. In: Developmental Psychology. [Fejlődéslélektan]. Cole, M., Cole, S. R. Osiris, Budapest. 2006, . Budapest : Osiris, 2006. old.: 426-445.

4. Baumrind, D. Child care practices anteceding three patterns of preschool behavior. hely nélk. : Genet Psychol Monogr, 1967. old.: 4388. 75. kötet.

5. Ranschburg, J. Love, morality, autonomy. [ Szeretet, erkölcs, autonómia]. Budapest : Integra-Projekt Kft., 1993. old.: 22-25. [Hungarian].

6. Moskola, V., Susánszky, É., Székely, A., et al. Examination of parental treatment among 
outgoing ambulance workers . [Szülői bánásmód vizsgálata kivonuló mentődolgozók körében. Budapest : Nővér,, 2020. old.: 27-33. 33. kötet, [Hungarian].

7. Copp, G. A Review of Current Theories of Death and Dying. 1998. old.: 382-390. 28. kötet, https://doi.org/10.1046/j.1365-2648.1998.00794.x.

8. Glaser, B. G., Strauss, A. L. The Problem of Awareness of Dying. In: Awareness of Dying. . London : Taylor \& Francis, 2017. old.: 1-26. Taylor \& Francis, London, 2017. 1-26. Av https:// books.google.ae/books?id=opcuDWAAQBAJ (Accessed: 24 February 2018)..

9. Pattison, E. M., Pattison, S. M. The Experience of Dying. hely nélk. : Prentice-Hall, Upper Saddle River, 1977. https://books.google.ae/ books/about/The_experience_of_dying.htm$\underline{\text { l? id }=J T 5 r A A A A M A A J \& r e d i r \_e s c}=y$ (Accessed: 24 February 2018).

10. Varga, Zs. K., Baksa, D., K. Szilágyi, A. Investigation of death attitudes and their correlations in critically ill nursing populations: among nurses working in intensive care units and in hospice care. Budapest : Kharón, 2009. old.: 8-54. 9. kötet, Hungarian.

11. Tauszik, K. Nehezen azonosítható kockázatok a munkahelyen. . 2014. http://met.ergonomiavilaga.hu/subsites/PT/MET_PT_TK.pdf (Accessed: 23 July 2020)..
12. Oláh, M. Death attitude and fear of death in nursing [Halálszemlélet és halálfélelem az ápolásban]. Budapest : IME, 2014. old.: 46-49. 13. kötet, [Hungarian].

13. Hegedűs, K., Zana, Á., Szabó, G. Medical students' image of death and effects of courses dealing with death and dying [Medikusok halálképe és a halállal, haldoklással foglalkozó kurzusok hatásai]. Budapest : Kharón, 2006. old.: 46-58. 10. kötet, [Hungarian].

14. Temesváry, B. Some specific aspects of the fear of death [A halálfélelem néhány sajátos aspektusa]. Budapest : Orv. Hetil., 1996. old.: 1419-1425. 137. kötet, [Hungarian].

15. Pék, E., Székely-Benke, Z., Betlehem, J., et al. Comparative analysis of attitudes of ambulance personnel and paramedic students regarding death and dying [Mentődolgozók és mentőtiszthallgatók halállal és haldoklással kapcsolatos attitüdjének összehasonlító vizsgálata. Budapest : ismeretlen szerző, 2015. old.: 1183-1187. 156. kötet, https://doi. org/10.1556/650.2015.30266.

16. Zana, Á. Death attitude and changes of death image in the Hungarian society. Examination of generational value-judgment and possibilities of measurement. Is death still a taboo? [A halálkép alakulása és változása Magyarországon, a korosztályos értékítélet-külömb- 
Népegészségügy - Eredeti közlemény / Public health - Original article

sé. Budapest : ismeretlen szerző, 2009. old.: 1183-1187. 150. kötet, https://doi.org/10.1556/ OH.2009.28577.

17. Csomortáni, D. Z. Too good / bad enough parents causes, characteristics, consequences and treatment options for psychological overprotection [Túl jó / elég rossz szülők a pszichológiai túlvédés okai, jellemzői, következményei és kezelési lehetőségei]. Budapest : ELTE, 2014. PhD disszertáció, https://doi. org/10.15476/ELTE.2014.064. 